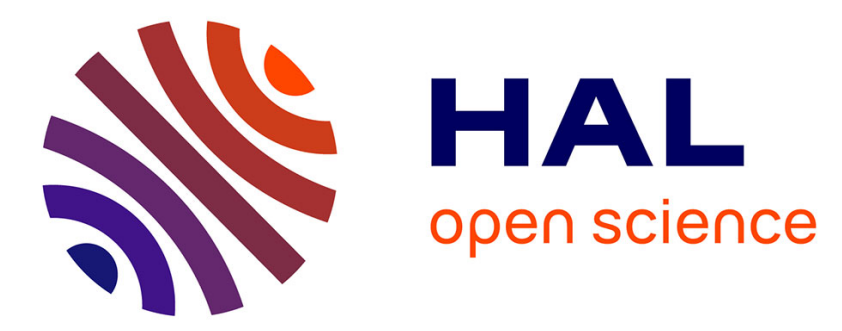

\title{
From useful to invasive, the status of gorse on Reunion Island
}

\author{
Nathalie Udo, Catherine Darrot, Anne Atlan
}

\section{To cite this version:}

Nathalie Udo, Catherine Darrot, Anne Atlan. From useful to invasive, the status of gorse on Reunion Island. Journal of Environmental Management, 2019, 229, pp.166-173. 10.1016/j.jenvman.2018.06.036 . hal-01827712

\section{HAL Id: hal-01827712}

\section{https://institut-agro-rennes-angers.hal.science/hal-01827712}

Submitted on 18 Sep 2018

HAL is a multi-disciplinary open access archive for the deposit and dissemination of scientific research documents, whether they are published or not. The documents may come from teaching and research institutions in France or abroad, or from public or private research centers.
L'archive ouverte pluridisciplinaire HAL, est destinée au dépôt et à la diffusion de documents scientifiques de niveau recherche, publiés ou non, émanant des établissements d'enseignement et de recherche français ou étrangers, des laboratoires publics ou privés. 


\title{
From useful to invasive, the status of gorse on Reunion Island
}

\author{
Nathalie Udo ${ }^{1,2}$, Catherine Darrot ${ }^{3}$, Anne Atlan ${ }^{1,2}$ \\ ${ }^{1}$ UMR 6590 ESO, CNRS/Université Rennes Place du recteur Henri Le Moal. F-35043 Rennes, \\ France \\ ${ }^{2}$ UMR 6553 ECOBIO, CNRS/Université Rennes 1, bât. 14A, Campus de Beaulieu. F-35042 \\ Rennes, France \\ ${ }^{3}$ UMR 6590 ESO, Agrocampus Ouest, 65 Rue de Saint-Brieuc, 35000 Rennes, France \\ nathalie.udo88@gmail.com \\ catherine.darrot@agrocampus-ouest.fr \\ anne.atlan@univ-rennes2.fr
}

\begin{abstract}
:
Species presently considered as invasive were often deliberately introduced. Which factors led them from being desired to being denounced and what trajectory did such a transition follow? Using the case of common gorse (Ulex europaeus) on Reunion Island, the aims of this study were first, to identify and describe the different status that were attributed to this species since its introduction; and second, to discern the factors that influenced their emergence and decline in the public sphere. Five types of status were identified for common gorse in Reunion (useful, nationalistic, indigenized, noxious weed, and invasive), each peaking at a certain time, and then reverting to a low-key presence. The emergence and dissemination of each status in the public sphere depends on how well the various narratives proposed about the plant by networks of legitimate actors match the socio-technical landscape, as well as on how these narratives appear within legal and institutional frameworks. In addition, translating a status into actions of management can bolster its trajectory in the public sphere. Lastly, the decline of a status can be explained by a gradual desynchronization between its cognitive, normative and/or instrumental dimensions and the local socio-technical landscape.
\end{abstract}

Keywords: Invasive species, status, socio-technical landscape, Reunion Island

\section{Introduction}

Species considered as invasive were often introduced long before the emergence of the concept of biological invasions. In addition, many of them were deliberately introduced, for agricultural or ornamental purpose. The transition from being desired to being denounced as invasive has been much less studied than the variety and the complexity of categorizations of these species. Since the first sociological studies on invasive species, the variety of categorization processes has been brought to light. Different groups of actors (e.g., scientists, environmental managers, naturalists, 
farmers, hunters or walkers) may categorize a species differently, depending on their relationship with nature, the potential impact on their activity, their attachment to the species, and their sensitivity. The categorization of species as invasive, supported by scientific ecologists and environmental managers, does not reflect the range of categorizations established by other actors (e.g. Javelle et al., 2006; Menozzi, 2010; and in this issue, Kull et al., Bach et al., Bennet and Van Sittert). Even among scientists and environmental managers, the categorization is variable, and the perceptions, definitions, terminologies and metaphors used have been critically discussed (Larson, 2007; Davis et al., 2011; Humair et al., 2014).

Sociological studies on animals have shown that the categorization of a given species is highly dependent on time, place, local political priorities, and the value system (See Estevez et al 2015 - Shackleton et al this issue). It also depends on the social elaboration of the risk caused by the species, and on the level of risk considered as acceptable. For example, Mougenot and Roussel (2006) and Migot (2006) studied the case of the coypu (Myocastor coypus) in France and showed that this animal, currently considered as "invasive", was formerly considered as "exotic", "domestic", "wild" or "noxious". Similar conclusions have been drawn regarding the European rabbit (Oryctolagus cuniculus) (Van Dam, 2001; Mougenot and Strivay, 2011). Historical studies dedicated to invasive plants are less common. The historian van Sittert (2002) traced the changes of categorization of the Barbary fig (Opuntia ficus-indica) in South Africa from "useful" to "noxious." He explained the evolution observed in the spread of the species to new types of area, by particular environmental or economic characteristics of the species itself, and by the evolution of cultural values. The biologist Starfinger et al. (2003) showed that the successive categorization of the black cherry tree (Prunus serotina) depended on a value system being integrated into different scientific studies and being used to justify control measures. To study the factors influencing the transition from one categorization to another, we propose the concept of status.

We will use the term "status", initially proposed for humans by Linton (1945), to describe the place attributed to a species in a given social system at a given moment. The social status is situated in a historical and social context, and constitutes an indicator of the functions, socioeconomic position and social prestige of a person - here a species - in the society (Weber [1921]1995; Parsons, 1945: Linton 1945). The concept of status does not imply any a priori social visibility, while the concepts of "perception" or "representation" imply a cognitive construction or social visibility, and are therefore not always relevant for invasive species (e.g. Javelle et al., 2006, Thian-Bo Morel and Duret, 2011; Shackleton et al., this issue). In addition, a status can reflect the skills, abilities, and efforts of a person (Linton, 1945), so it is linked to the attributes of the individual. Applied to plants or animals, the concept of status makes it possible to link the biophysical characteristics of a species to its place in the social system, and thus to make the link between its natural and social dimensions.

We will distinguish between "public status" (i.e., status carried by public groups, such as state institutions, recognized authorities or organized groups) and "silent status" (i.e., supported by isolated individuals or groups deprived of a voice in the public sphere). From a methodological point of view, the emergence of a given issue in the public sphere can be identified through specialized documents (e.g., scientific publications, technical guides, regulatory texts) and general publications (e.g., newspapers, school textbooks, travel guides) (Thévenot, 2001; Boudes and Darrot, 2016). We propose the word "publicization" to designate the processes and media by which an issue is integrated and gains visibility in the public sphere (Henri, 2005; Carrel, 2015). 
To trace the transitions of public status that have occurred over a long period, it is practically advantageous to work on a species that is easily recognizable and that can be correctly identified even in older texts. This is the case of common gorse (Ulex europaeus), a spiny shrub introduced into European colonies during the $19^{\text {th }}$ century for agricultural purpose (mainly fodder and hedges, Atlan et al., 2015) and which is now considered to be a major invasive plant in many parts of the world (Lowe et al., 2000). We chose a confined study region, with relatively easy access to archives and public documents: Reunion Island, a French overseas territory in the Indian Ocean. The history of the geographic expansion of gorse on this island has been accurately studied and substantial information is available regarding its socio-ecology and biology (Hornoy et al., 2011; Udo et al., 2016; Udo et al., 2018).

The aims of this study were first, to identify and describe the status that have been attributed to gorse in Reunion Island since its introduction; and second, to discern the factors that influenced its trajectory of publicization. The article is divided into three parts. The first part sets out our data collection methods and data analysis framework. The second part details the different types of status identified and the periods in which they dominated the public sphere. The third part identifies the factors that have contributed to their emergence, publicization and transition in the public sphere.

\section{Methods}

\subsection{Study region: the Reunion Island}

Reunion is a small, mountainous, tropical island in the south west Indian Ocean $\left(2512 \mathrm{~km}^{2}\right.$, highest peak $3069 \mathrm{~m}$ ). A permanent colony was first established by the French at the beginning of the 17th century. Alongside the French colonizers, the island was populated by different ethnic groups from Africa and Asia partly due to the slave trade. The low-lying areas of the island were colonized first because they were the most accessible and most fertile. Attempts to develop the highlands (over $500 \mathrm{~m}$ above sea level), notably for livestock farming, only started in the second half of the 20th century. Owing to the difficulty of access, these areas are still sparsely populated and retain numerous indigenous and endemic species. They are of particular interest for the conservation of biodiversity (Strasberg et al., 2005). Most highlands of the Island were integrated into the Reunion National Park in 2007, and acquired the UNESCO world heritage label in 2010. Part of these highlands are dedicated to agriculture and are not included in the heart of the National Park. From the 1980s-1990s, the development policy applied to these areas was largely structured around promoting cattle farming (Guellec, 1992). The highlands are recognized as bearing witness to 'Creole identity' and have been subject to specific social organization and uses (Dalama 2006).

In Reunion, gorse was planted for the first time in natura in 1850 (Udo et al., 2016). It grows only in highlands, over $1000 \mathrm{~m}$ above sea level, where it has spread in both agricultural and natural areas. After 1980 and livestock farming development programs promoted the control of gorse, since then the density of gorse populations has decreased significantly in agricultural areas, but it continues to expand in natural areas. The major stages of the establishment of gorse on the island are summarized in Table 1. 
Table 1. Main stages of the spatial-temporal dynamics of common gorse on Reunion Island (adapted from Udo et al., 2016).

\begin{tabular}{|l|l|}
\hline $1825-1860$ & $\begin{array}{l}\text { Gorse introduced into Reunion in the acclimatization garden based in St } \\
\text { Denis, the administrative centre of the island. }\end{array}$ \\
\hline $1850 \mathrm{~s}$ & $\begin{array}{l}\text { Plantation in an agricultural zones and subsequent establishment of } \\
\text { permanent populations }\end{array}$ \\
\hline $1900-1980$ & Geographic expansion of gorse in agricultural areas \\
\hline Since 1930 & Geographic expansion of gorse in natural areas \\
\hline Since 1980 & $\begin{array}{l}\text { Reduction in the density of gorse populations in agricultural areas but } \\
\text { expansion in natural areas }\end{array}$ \\
\hline
\end{tabular}

\subsection{Data collection and analysis framework}

The study was based on hundreds of written documents, and 41 semi-structured interviews. The type, volume and accessibility of documents vary between the beginning of the 19th and the 21st centuries. It was therefore necessary to collect extremely varied materials to be able to document the changing public status of gorse as accurately as possible, including work reports and technical guides, but also press articles and books intended for the general public (school textbooks, floras, narrations, travel guides). Semi-structured interviews were conducted with actors working on the issue of gorse and expressing themselves in the public sphere: scientists, environmental managers (Forest National Office, National Park, Sensitive Natural Areas), agronomists, engineers, and officials of local councils ("Departement", "Region") and administrations in charge of environment, agriculture or forestry ("DEAL"-Direction de l'Environnement, de l'Aménagement et du Logement), "DAAF"-Direction de l'Alimentation, de l'Agriculture et de la Forêt). Interviews were also conducted with stakeholders concerned by the expansion of gorse because of the geographical proximity of their professional activities (mainly cattle farmers). Lastly, exploratory interviews with the public attending natural or agricultural areas occupied by gorse were also carried out.

To characterize each status, the various descriptions of gorse were analyzed on the basis of the documents and interviews in terms of factors such as the following: given name, descriptive adjectives, biological characteristics described, and the nature of the justification.

Five public types of status were identified, each structured around a particular combination of human-plant relationships, justified by different types of argumentation, and associated (or not) with specific management measures. We chose the organized narrative approach (Cortazzi, 2001; Elliot, 2005) to present our findings. A quantitative indicator was chosen to fully assess the periods of publicization of each status: the number of institutional and academic documents publicizing each status (Figure 1). Other types of document were more difficult to collect exhaustively and were thus subject to qualitative analysis. We analyzed as many information sources as possible concerning both the publication itself and its authors: affiliated institution, education, career, social background, involvement in local networks, and any professional or personal relationships between actors.

The emergence of each public status and the transition from one status to another was analyzed using the emergence of conflict between arguments, the tension between the groups voicing these arguments, and the overlap between the pre-existing narrative and the new narrative. 
The Multi-Level Perspective (MLP) (Geels, 2002; Geels and Schot, 2010) is used to explain sociotechnical transitions by the arrangement of different dimensions and scales in a diachronic coevolution. Inspired by the MLP, we considered the evolution of the public status of gorse in Réunion as a socio-technical transition, articulating biophysical (natural) and social factors. We consequently focused on the three following scales of events for our analysis:

i) the context factors (socio-economic, technical and scientific) that influence the relationships between humans and nature (inspired by the notion of "socio-technical landscape" developed in the MLP);

ii) the established practices and associated rules allowing a status to last (i.e., the methods used to manage natural and agricultural areas in Reunion), which was inspired by the concept of "socio-technical regime" in the MLP); and

iii) the non-publicized (or "silent") status of gorse at a given period (inspired by the notion of "niches of innovation" developed in the MLP).

\section{The five successive public status of gorse}

Over time, gorse has changed from being considered useful to being considered invasive, passing through phases as a nationalistic plant, an indigenized plant, and a noxious weed. Figure 1 shows the periods when each status was present in the public sphere, and Table 2 shows the biological characteristics of gorse that were respectively emphasized as well as the register of justification used.

\subsection{Useful plant}

The useful plant status was imported from the area of origin at the time of colonization. It therefore can be found in all regions where gorse was intentionally introduced. It was supported by agronomists that encouraged its exportation to the colonies for agricultural uses (Atlan et al., 2015). For example, the French agronomist Calvel (1809) stated that "This shrub, [...] offers, in some places, precious advantages for agriculture, advantages that are almost unknown in other countries or that are overlooked [Translated from the French]." The biological characteristics of gorse put forward are its high protein and nitrogen content - for cattle feed - and its ability to form spiny, dense and impenetrable thickets - for defensive hedges and fencing. In short, this public status is justified by an economic rationality.

This status was publicized in Reunion following the arrival of gorse on the island (Bréon, 1825). Various official publications show that gorse was cultivated by gardener-botanists in an acclimatization garden for at least 30 years. During the same period, livestock farmers planted gorse in natura (Udo, 2016).

Since the 20th century, agronomy publications that mention the potential of gorse in Reunion have become rare, and most often occur within the grey literature. Nowadays, some livestock farmers in Réunion use gorse for feeding goats. However, the majority of livestock farmers, since at least the 1950s, have used gorse more opportunistically as shelter for livestock, fuel, fencing to keep out stray dogs and poachers, and to keep livestock in (Murat, 2001; interviews with livestock farmers 2013-2014). The justification is both economic, involving rational thinking with the aim of properly taking care of the herd, and emotional, involving a human-plant relationship based on experience and tradition. These uses of gorse employed by livestock farmers are not anymore publicized. 


\section{5}

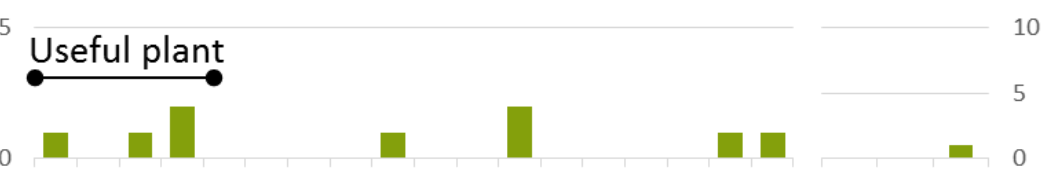

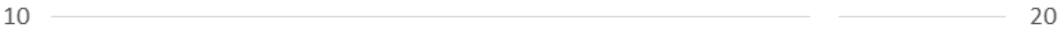
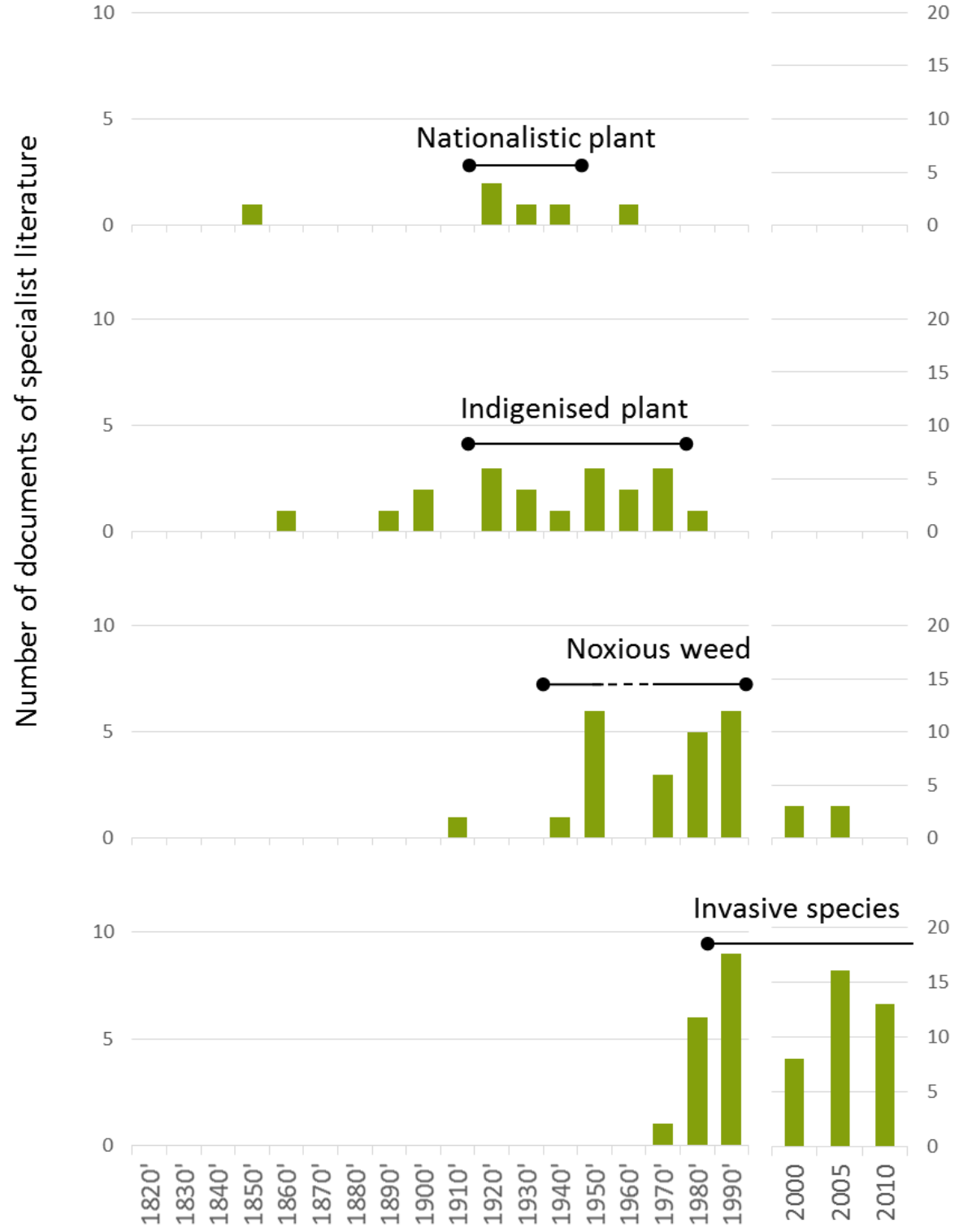

Fig. 1: Publicization of the various types of status attributed to gorse on Reunion from its introduction to 2014 (bibliometric analysis). The number of documents published and digitalized is substantially higher from the 2000 s, so the scale was modified to make the intensity of status publicization comparable over time. 


\subsection{Nationalistic plant}

The public status of nationalistic plant was supported in the 19th century by colonists who had grown up in metropolitan France. The highlighted attributes of the plant are its geographic origin and its beautiful flowers. This status is clearly part of an emotional human-plant relationship: beside agronomic purpose, it is likely that gorse was planted with the aim of maintaining a link with homeland. In 1858, during the Romantic era, the colonist Moreau (1858) wrote about his joy and emotion at having come across a little gorse plant, "this humble brother," during an agricultural fair: "Suddenly, as if with the wave of a magic wand, youth, nation, family, all the joys of the past, all the hopes for the future, all that beats in the heart of the absentee, all emerges at the sight of you, poor flower of memories, naive jewel of the beloved lands of our childhood."

This status was publicized between 1920 and 1950 by botanists of the National Acclimatization Society (Société Nationale d'Acclimatation, SNA), who wrote, in 1925, that the "gorse of Brittany [...] gives travelers a supreme vision of their motherland." It was also publicized by writers from Reunion, such as Marius-Ary Leblond, recognized pioneer of the colonial novel, who wished to "see the multiplication of photographs showing abandoned lands that gorse gilds just as abundantly as in Brittany (Leblond and Martineau, 1931)," and by geographers publishing in colonial journals.

Today, this status is no longer publicized by people who had been long established there i.e. people who were born on the Island. However, our exploratory interviews with recent inhabitants of the island and tourists showed that gorse continues to evoke images of the French countryside.

\subsection{Indigenized plant}

The indigenous status appeared when gorse began to be described as part of the local vegetation. Furthermore, its "golden yellow flowers" is described as illuminating and brightening up a landscape otherwise perceived as dark and gloomy (e.g. Bertile, 1978). We have linked these two aspects under the status of indigenized plant because they were publicized by the similar actors during the same period. The highlighted attributes are the architectural form, which resembles indigenous species, and its flowering. This public status is linked to geographers' expertise in natural environments, but the justification is also emotional and value orientated: gorse is integrated into the countryside and is appreciated for its colorful, abundant and long-lasting flowers.

In 1895, botanist Jacob de Cordemoy wrote in his flora of Reunion that gorse "has the appearance of an indigenous plant". Later, the indigenization of gorse was largely publicized by French geographers carrying out research on the island, and covered within $\mathrm{PhD}$ theses, reports, books and geography textbooks. Between 1960 and 1980, the arrival of public service employees also contributed to the publicization of this status via different mediums mostly targeted toward the general public (e.g., novels, historic works, photo books, postcards and travel guides). Up to now, some travel guides still show appreciation for gorse and its integration into the landscape; for example, Le Petit Futé (2013) observes that "mist hugs a stunning landscape of gorse and broom, whose beautiful yellow color shines out from August to November, standing out against the blue morning sky".

The interviews performed between 2012 and 2014 showed that this status was still attributed to gorse by hikers, walkers and picnickers in high altitude natural areas. For example, a tourist stated, that "gorse is the color that enhances the beauty of the place" and a Creole inhabitant stated that "it has always been here, since the creation of the world". 


\subsection{Noxious weed}

The noxious weed status was attributed to gorse in high altitude farmlands, when it began to expand into meadows and reduce useable pastures. This status emerged when farmers realized that its control was difficult and could be extremely costly in terms of time and money. The highlighted attributes are its rapid growth, its high level of seed production (up to 10000 seeds per plant per year), and its ability to regenerate after cutting or fire. The argumentation is based on scientific (agronomic) viewpoints.

In Reunion, this status emerged in the 1920s; it then went through two phases of publicization, one in the 1950s and the other between 1970 and 2000. During the first period, the status was mainly publicized by agronomists, who published articles in the Reunion agricultural journal. During the second period, it was publicized by a larger number of actors: agricultural institutions (e.g., Agricultural Research for Development-livestock farming (CIRAD-élevage), Blanfort, 1996) or research institutions for development (e.g., Reunion Association of Pastoralism - 1991; National Forest Office, ONF 1987; Barbet-Massin et al., 2003), as well as by other types of actors, such as journalists, writers and geographers (e.g., Vailland, 1964). Funding for livestock farming development (including the struggle against gorse) comes from the regional authority, the French government and Europe. Since 2000, the publicization of this status is reinforced by a normative dimension and gorse was included in the decree of the Ministry of Agriculture and Fisheries establishing the list of pests subject to control measures in Reunion.

In 2014, the status of noxious weed was no longer publicized by institutional actors as most of them consider that its propagation is controlled or controllable. According to them, the farmers are responsible for the presence of gorse because of their choice of cultivation practices. The fact remains, however, that the spread of gorse was still a major concern for livestock farmers, who observed that "grass does not grow under gorse and that is a part of the plot wasted" and that "it has to be got rid of as it's a pest for cows, it scratches your hands, it also scratches the cows, and it takes the place of grass. Nothing grows around it".

\subsection{Invasive plant}

The currently publicized status of gorse is that of invasive plant, not only in Reunion, but also on a global scale. The justification is scientific (conservation ecology and biology): academic literature and grey literature indicate that, due to its ability to spread rapidly and its susceptibility to fire, gorse is a threat to indigenous and endemic species. The publicization of this status is reinforced by a normative dimension: in natural areas, detailed official management strategies are set up for controlling gorse and, further, it is mandatory to struggle against gorse in agricultural areas in order to protect adjacent natural areas. This status is also justified by conceptual arguments: environmental actors invoke the primacy of the indigenous vegetation and "totally yellow landscape that has no place in the island's vegetation," which is sometimes expressed in an emotional register, such as "All this yellow, it makes me want to cry".

In Reunion, the invasive species status appeared at the end of the 1970s. It was justified by the plant's negative impact on both natural and agricultural areas, and, in this way, overlapped with the noxious weed status. However, the biological attributes of the plant highlighted are more numerous, in addition to its rapid growth, its high level of seed production, and its ability to regenerate after cutting or fire they include its flammability and exotic origin. This status was first supported by botanists from the Association for the Protection of Nature (Dupont, 1988-2000; Lavergne, 1978), biology researchers at University of Reunion, and a deputy director of the 
National Forest Office (Figier and Souleres, 1991). From the middle of the 2000s, its publicization increased, principally due to the management actions and technical documents produced by the National Forest Office (e.g., Sigala, 2001; Triolo and Hoff, 2006) and by scientific publications of researchers in ecology and conservation biology (e.g., Baret et al., 2006; Kueffer and Vos, 2003; Tassin et al., 2006).

Gradually, attention focused on the impact of gorse on the natural environment. Other public actors joined the debate and took part in the publicization of gorse's invasive status: agents of the Reunion National Park (Payet, 2012), representatives from different ministries (Creuchet et al., 2012), UNESCO (2013), private sector engineers (e.g., Asconit-Pareto, 2011; Cyathea, 2011) and researchers in evolutionary ecology (e.g., Hornoy et al., 2011). The invasive status appeared in specialized press articles as well as in regional and national daily newspapers. Beside these institutions, few people spontaneously attribute the status of invasive plant to gorse.

Table 2. The different public statuses of gorse: biological characteristics targeted and types of argumentation invoked.

\begin{tabular}{|c|c|c|c|c|c|}
\hline & Useful & Nationalistic & Indigenized & Noxious & Invasive \\
\hline $\begin{array}{l}\text { Rich in protein and } \\
\text { nitrogen fixation }\end{array}$ & $\mathbf{X}$ & & & & \\
\hline $\begin{array}{l}\text { Spiny and dense } \\
\text { structure }\end{array}$ & $\mathbf{X}$ & & & $\mathbf{X}$ & \\
\hline $\begin{array}{l}\text { Ability to adapt } \\
\text { to local conditions }\end{array}$ & $\mathbf{X}$ & & $\mathbf{X}$ & & $\mathbf{X}$ \\
\hline $\begin{array}{l}\text { Seed production } \\
\text { and dispersal }\end{array}$ & & & & $\mathbf{X}$ & $\mathbf{X}$ \\
\hline $\begin{array}{l}\text { Rapid growth and } \\
\text { regeneration }\end{array}$ & & & & $\mathbf{X}$ & $\mathbf{X}$ \\
\hline $\begin{array}{l}\text { Flammability } \\
\text { and pyrophily }\end{array}$ & & & & & $\mathbf{X}$ \\
\hline $\begin{array}{l}\text { Originating from } \\
\text { mainland France }\end{array}$ & & $\mathbf{X}$ & & & $\mathbf{X}$ \\
\hline $\begin{array}{l}\text { Architectural form } \\
\text { and appearance }\end{array}$ & & & $\mathbf{X}$ & & \\
\hline $\begin{array}{l}\text { Colourful and } \\
\text { fragrant flowering }\end{array}$ & & $\mathbf{X}$ & $\mathbf{X}$ & & \\
\hline $\begin{array}{l}\text { Main } \\
\text { argumentation }\end{array}$ & $\begin{array}{l}\text { Agronomic } \\
\text { Economic }\end{array}$ & $\begin{array}{l}\text { Emotional } \\
\text { Aesthetic }\end{array}$ & $\begin{array}{l}\text { Conceptual } \\
\text { Emotional }\end{array}$ & $\begin{array}{l}\text { Technical } \\
\text { Economic }\end{array}$ & $\begin{array}{c}\text { Scientific } \\
\text { Conceptual }\end{array}$ \\
\hline
\end{tabular}

\section{Factors involved in status emergence, publicization and transition}

\subsection{Levels of publicization}

Each public status showed a different level of publicization. The expression of a status in normative texts and technical management contributed to strengthen its trajectory and increase the number of 
public arenas where it was promoted. These phenomena have been particularly prevalent for the noxious weed status and the invasive plant status.

From the 1950s, and even more so from the1990s, different control measure plans were created and published by institutional agricultural bodies (ONF, 1987; Raunet, 1991; Barbet Massin et al., 2003) and significant public measures were designed and funded for livestock farmers to undertake such actions (Udo et al., 2016). The plant causes difficulties to the new, modernized agricultural model, as illustrated by the substantial work of mechanically removing, uprooting or clearing gorse in visible agricultural environments.

Since the beginning of the 2000s, the invasive status also led to numerous forms of technical management, including uprooting, regular cutting, and chemical treatments (that may have to be carried out several times a year). The natural areas where management has been performed are smaller than the agricultural areas managed in the context of the noxious weed status, but the invasive status has gained visibility because several of these zones are popular tourist destinations, where on-site signs explain the nature of the management being done (e.g., "Fight against invading plant species ... Removal of common gorse ... Planting of endemic species").

Environmental actors almost exclusively focused on natural environments, but the invasive status and the addition of gorse to the list of the island's principal invasive species had consequences on other parts of the island. For example, in 2006, a prefectural decree prescribed that removing gorse from cultivated areas is henceforth a condition for receiving European farming aids. In public agricultural spaces granted to livestock farmers, the decree was bolstered by an obligation to struggle against gorse in both productive and non-productive areas. Other professionals, working in quarrying or forestry, were required to take measures to avoid spreading gorse seeds via machines and vehicle wheels. Although the useful plant status, the indigenized plant status and the noxious weed status still maintain a low-key presence, the high volume of regulatory texts currently allow the invasive plant status to dominate the public sphere.

\subsection{Co-evolution of the socio-technical landscape and public status}

The first four status of gorse were publicized between 1825 and 1990, at a time characterized by colonization and decolonization, as well as by technological development and by the transformation of French agricultural systems. This was the end of the period referred to as "modern era" in social sciences (Berman, 1982).

The publicization of the useful plant status was part of a wave of species introductions by colonial administrations with the goal of developing business or addressing local technical and economic needs, at a time were acclimatization gardens were frequent. At this time, few efforts were made to find local solutions to local problems, and indigenous species were often labelled as inappropriate (Mack, 2001).

The publicization of the nationalistic plant status corresponds to the "call home syndrome" described by Mack (2001). Colonists chose species from their native country, feeling safe and at home when surrounded by familiar plants. Gorse seeds, "as little as they are, remained the seedlings of a way of life, the promise of a fertile symbiosis between man and plant (Lavergne, 1980)." During the two World Wars, a time when communication between France and the colony was limited and when the people of Reunion felt abandoned (Vaxelaire, 2012), the publicization of this status intensified.

The publicization of the indigenized plant status was first done by explorers. It became increasingly popular when numerous public service employees arrived from mainland France and

made recreational use of the island's landscapes during their free time (Vaxelaire, 2012), notably in the highlands (Robert 1998). This status was therefore particularly significant in areas used for 
leisure and contemplation. Gorse-covered areas play a role in the substantial diversity of the landscapes found on the island. Such diversity of landscape was lauded - together with the diversity of human beings and cultures - as a part of the identity of Reunion (Colette, 2001).

The publicization of the noxious weed status in the 1950s was directly linked to a desire to modernize and intensify agriculture, following what was being established in mainland France. The government therefore encouraged intensive agricultural production so the island could become more autonomous. In 1946, Reunion became a "Department" (it acquired the same administrative status than if it was located in France mainland), and the National Forest Office took over management of the highlands. It advocated more rational and settled agriculture, as it allowed the extensive pastures in natural and forest areas to be controlled (ONF, 1987). At the end of the 1970s, a desire to stabilize the population in the highlands led to the promotion of livestock farming, with the aim of developing economic activity and social ties, in accord with the development model that had emerged across Europe for rural zones in decline.

Since 1900 and through the end of the 1980s (i.e. during the late modern period, Berman, 1982), publications seem to deal with cultivated areas from technical and economic perspectives, whereas wild nature was considered from a more romantic point of view. Ecological problems were rarely publicized. A major turning point took place at the end of the 1980s, characterized by questioning the ideas of nature as inexhaustible and indestructible. The negative effects of anthropogenic pressure on the environment, as well as globalization and the standardization of societies and nature, were denounced. An awareness of the damage caused by human activity was translated into institutional and political frameworks throughout the world. Ecology became a metascience that also acquired a cultural and social dimension (Deléage, 1991). A sense of responsibility arose and developed towards future generations as well as towards non-humans, such that nature had to be protected for its own sake. This was the context in which the concept of biodiversity took root. This concept tends to encourage the distinction between endemic and exotic species, endemic species being considered as the biodiversity that needs to be protected, and exotic invasive species being considered as one of the main threats to this biodiversity.

The publicization of gorse as an invasive plant is part of a desire to preserve the indigenous and endemic biodiversity of Reunion. It has relied on the increase in publications on invasive species at regional, national and international levels since the end of the 1990s (Udo, 2016). The particular attention paid to gorse in Reunion is justified at both international level (it is one of the ' 100 of the world's worst invasive alien species' published in 2000 by the IUCN), and locally, where it grows in the natural habitat with the least anthropic influence and where the management of invasive species is one of the conditions for keeping the UNESCO World Heritage label.

\subsection{Networks of actors}

The status of gorse that succeeded in the public sphere have all been publicized by advocates educated in natural sciences: botanists, geographers, agronomists, environmental managers and ecologists. Their recognized expertise and their rhetorical and conceptual skills enhance their credibility, authority and ability to impose their way of thinking in public arenas, as well as in political, legal and media spheres. Personal and professional relationship between actors also contributed to the emergence and stabilization of a given status in the public sphere.

The relationships between the different actors promoting the "useful plant" status were numerous. For example, Mr Lépervanche was both a livestock farmer and a forest inspector (Jacob de Cordemoy, 1895), and Mr Bois Joli Potier was both a livestock farmer and an elected member of the local council. His opinions were a reference point for the officials organizing the colonization of the highlands (Vaxelaire, 2012). Gardener-botanist Bréon received gorse seeds from his brother. 
Lépervanche and Richard, Bréon's successors, exchanged correspondence on botany. Lastly, Dr Bernier, to whom we can also attribute the introduction of gorse to the island (Moreau, 1858), was Richard's son-in-law.

The "indigenized plant" status was publicized by geographers from mainland France and Reunion, with different professional connections, notably via research supervision or copublication, and by the numerous relationships maintained with members of local government entities (Babou, 2015).

Since the 2000s, the "invasive plant" status has been publicized by an established network of environmental actors, broadly working on themes relating to the protection of biodiversity and invasive biology. This network links members of local public institutions, administrations in charge of environment, agriculture or forestry, and associations for nature conservation as well as French ministries, and international structures (IUCN, UNESCO). The actors composing this network are linked by a significant number of strong ties that are both professional (former students, former colleagues) and personal (family, friends). In addition, the mobilization of new actors in the management of gorse in natural environments led to conflicts of legitimacy and to highly competitive data production, as well as to an increased media exposure of the invasive status (Udo, 2016).

According to Granovetter (2000), the strength of the ties between two individuals is characterized by the combination of time spent together, emotional intensity, mutual trust and reciprocal services. In dense networks, strong ties mean that information known to one member rapidly circulates to all members, which can favor cognitive routines. Furthermore, members of these networks do not seriously question the words of their close friends, relatives, or colleagues (Callon and Latour, 1991). Consequently, these interconnected relationships strengthen coalitions and social cohesion via the exchange of information within a limited group. They were therefore able to act as catalysts for the emergence, publicization and stabilization of a status over time.

\section{Conclusion}

We have identified five public status of gorse in Reunion, each one peaking at a certain time and maintaining a low-key presence after its principal success period. Its status as an invasive plant, which clearly dominates in the public sphere today, coexists with earlier status, especially as a noxious weed in farmlands of high altitude.

The same trends in the succession of status of gorse can be found in other countries. In New Zealand, Isern (2007) identified at least three successive "lives" of gorse: "useful plant", "noxious weed" and "invasive species." The study conducted by Bagge (2014) on perceptions of gorse in New Zealand from 1835 to 2000 also reveals similarities with our study. There, too, in the 19th and 20th centuries, gorse was used as a hedging plant, wind break, stock control, firewood, feed for goats and shelter for animals. It was considered a homeland plant, but also an enrichment of the New Zealand landscape. From the end of the 19th century, it became a common weed and, in 1990, New Zealand's worst weed. However, Bagge's study also shows differences with the case of Reunion: the noxious status was publicized earlier in New Zealand, mobilized many more politicians and led to the publication of numerous regulatory texts. Moreover, even though perceptions of gorse became increasingly negative in the 20th century, the status of gorse remained ambiguous and no general consensus emerged. In 2000, gorse was a noxious weed but was also considered as a nurse crop for the regeneration of native forest, a nitrogen fixer and a benefit for apiculture. 
Analogies can also be found with other invasive species in other countries. For example, the black cherry tree in Europe was considered useful when it was introduced in the 18th and 19th centuries (as valuable wood, improved litter under resinous trees, fire break), then was considered noxious in cultivated areas from 1960 to 1990, and then a threat to indigenous plant diversity from the end of the 1990s (Starfinger et al., 2003). The study of the transition between the different states of gorse can thus potentially highlight other trajectories.

Studying the status of gorse in Reunion, we have shown that the emergence and domination of a given public status of a species results from a match between biophysical characteristics (of the species and of the natural or agricultural spaces where it grows) and socio-technical landscapes (at local and global scales). However, the domination of a status in the public sphere relies not only on the overlap between context-dependent effects and the narratives proposed on the species: it is also dependent on the networks of actors legitimized by this context and on the transformation of such narratives and knowledge into legal and institutional frameworks. Furthermore, the translation of a status into technical practicalities and managements (its actualization, beyond the world of ideas) bolsters its ability to conquer the public domain. These elements play a role at the national and local scale mostly, and can contribute to explain the differences regarding the status of a given species between countries.

The decline of a status appeared to be a top-down process: when the status of gorse no longer matches the context framework, the advocates diffusing this status in the public sphere begin to lose their legitimacy (unless they change their discourse). The invasive plant status of gorse in Reunion is currently thriving. It appears to be benefiting from a relatively stable phase coherently bridging the socio-technical landscape, the socio-technical regime of the management of the island's natural and agricultural areas, and the international narrative proposed for gorse. However, this situation is not as stable as it appears: the scientific field and large environmental institutions are engaged in global debates regarding the role of humans in the regulation of natural processes, the choice of the techniques used, and even the notion of nature itself. These changes in the sociotechnical landscape currently challenge the legitimacy of the notion of invasive species and of the control measures that are generally proposed (e.g. Bonanno, 2016; Schlaepfer, 2018.). The growing worldwide success of localist technical and economic models is another significant global change (Hess, 2009). Such models count on integrated and more autonomous growth based on various local resources, potentially including invasive species. The concept of novel ecosystem (Hobbs et al., 2009) also might contributes to the emergence of a less radically negative status of species currently considered as invasive. The succession of the status of gorse is still ongoing.

\section{Acknowledgements}

We thank all the people who were interviewed. We are grateful to Luc Gigord and the scientific team of the National Conservatory of Botanics of Mascareigne for their help during the field work in Reunion. We thank Helen McCombie-Boudry for the first translation into English and Monique Péron for English edition. We thank the anonymous referees and the invited editors for their positive comments and suggestions to improve he manuscript. We thank the French National Research Agency (ANR MARIS research program), the French Society of Botany, and the Observatory OSUR for their financial support. 


\section{References}

Asconit-Pareto, 2011. Etude de Vulnérabilité Aux Changements Climatiques. Evaluation Qualitiative. SaintDenis, La Réunion.

Association Réunionnaise de Pastoralisme (ARP), 1991. Potentialités agro-pastorales de terrains des Hauts du Massif de la Fournaise. La Réunion, 71 p.

Atlan, A., Udo, N., Hornoy, B., Darrot, C., 2015. Evolution of the uses of gorse in native and invaded regions: What impacts on the dynamics and management? Terre Vie, 70(12).

Babou, I., 2015. Patrimonialisation et politiques de la nature : le parc national de La Réunion. VertigO

Bagge, M.L.S., 2014. Valuable ally or invading army? The ambivalence of gorse in New Zealand, 18351900. Environ.Nat.N. Z. 9.

Bennett, B., van Sittert, L. This issue. Historicising perceptions and the national framework for invasive alien plants in South Africa. J. Environ. Manage.

Bach, T.M., Kull, C.A., Rangan, H. This issue. From killing lists to healthy country: Aboriginal approaches to weed control in the Kimberley, Western Australia. J. Environ. Manage.

Barbet-Massin, V., Grimaud, P., Michon, A., Thomas, P., 2003. Guide technique pour la création, la gestion et valorisation des prairies à la Réunion. Saint-Pierre, La Réunion.

Baret, S., Rouget, M., Richardson, D.M., Lavergne, C., Egoh, B., Dupont, J., Strasberg, D., 2006. Current Distribution and potential extent of the most invasive alien plant species on La Reunion (Indian Ocean, Mascarene Islands). Austral Ecol 31, 747-758.

Berman, M., 1982. All That Is Solid Melts into Air: The Experience of Modernity, Simon and Schuster, New York.

Bertile, W., 1978. Les Hauts de La Réunion. Etude géographique. Géographie 15-66.

Blanfort, V., 1996. Agroécologie des pâturages d'altitude à l'île de La Réunion. Pratiques d'éleveurs et durabilité des ressources herbagères dans un milieu à fortes contraintes. Université de Paris-sud

Boudes, P., Darrot, C., 2016. Biens publics : construction économique et registres sociaux. Rev. Régulation Capital. Inst. Pouvoirs, 19.

Bonanno, G. 2016. Alien species: To remove or not to remove? That is the question. Environmental Science \& Policy 59:67-73.

Bréon, N., 1825. Catalogue des plantes cultivées aux jardins botanique et de naturalisation de l'île Bourbon. De l'Imprimerie du Gouvernement, Saint Denis, La Réunion.

Callon, M., Latour, B., 1991. La science telle qu'elle se fait: anthologie de la sociologie des sciences de langue anglaise. La Découverte, Paris.

Calvel, E., 1809. Mémoire sur l'Ajonc ou Genêt épineux, considéré sous le rapport de fourrage, de l'amendement des terres stériles et de supplément au bois. Marchant, Paris.

Carrel, M., 2015. Politicization and publicization: the fragile effects of deliberation in working-class districts, Eur. J. Cult. Polit. Sociol, 2, 189-210.

Colette, Y., 2001. Île de La Réunion paysages et identité. Saint-André, La Réunion.

Cortazzi, M., 2001. Narrative Analysis in Ethnography, in Atkinson, P., Coffey, A., Delamont, S., Lofland, J., Lofland, L. (eds.), Handbook of Ethnography, London, Sage: 384-394.

Creuchet, B., De fürst, X., Madigner, M.-L., Lafitte, J.J., Sauvage, P., 2012. Rapport de La Mission d'appui, suite aux incendies de forêt de La Réunion. Paris.

Cyathea, 2011. Etude test du guide d'évaluation économique des programmes de lutte contre les EEE à La Réunion. Bureau d'études Cyathea pour la Direction Régionale de l'Environnement Réunion.141 p.

Dalama, M.-G., 2006. L'île de la Réunion et le tourisme : d'une île de la désunion à la Réunion des Hauts et Bas. L'Espace Géographique 34, 342-349.

Davis, M.A., Chew, M.K., Hobbs, R.J., Lugo, A.E., Ewel, J.J., Vermeij, G.J., Brown, J.H., Rosenzweig, M.L., Gardener, M.R., Carroll, S.P., Thompson, K., Pickett, S.T., Stromberg, J.C., Del Tredici, P., Suding, K.N., Ehrenfeld, J.G., Grime, J.P., Mascaro, J., Briggs, J.C., 2011. Don't judge species on their origins. Nature 474, 153-154

Deléage, J.-P., 1991. Histoire de l'écologie: Une science de l'homme et de la nature. La Découverte. Paris

Dupont, J., 2000 Inventaire des ZNIEFF 1988-2000. Ministère de l'environnement - SREPEN, Saint-Denis, La Réunion. 
Estévez, R.A., Anderson, C.B., Pizarro, J.C., Burgman, M.A. 2015. Clarifying values, risk perceptions, and attitudes to resolve or avoid social conflicts in invasive species management. Conserv. Biol. 29(1):19-30.

Elliot, J., 2005. Using Narrative in Social Research. Qualitative and Quantitative Approaches. London: Sage Publications, $232 \mathrm{p}$.

Figier, J., Souleres, O., 1991. Le Problème Des Exotiques Envahissantes. Bois For.Trop. 229, 31-34.

Geels, F., 2002. Technological transitions as evolutionary reconfiguration processes: a multi-level perspective and a case study. Res.Policy 31, 1257-1274.

Geels, F., Schot, J., 2010. The dynamics of transitions: a socio-technical perspective. In: Grin, John, Rotmans, Jan and Schot, Johan (eds.) Transitions to sustainable development: new directions in the study of long term transformative change. Routledge, pp. 11-104.

Granovetter, M.S., 2000. Le marché autrement : les réseaux dans l'économie. Desclée de Brouwer, Paris.

Guellec, A., 1992. L'aménagement des Hauts à la Réunion. Ann.Géographie 101, 1-27.

Henri, E., 2005. Le droit comme vecteur de publicisation des problèmes sociaux. Effets publics du recours au droit dans le cas de l'amiante, in Liora Israël, Guillaume Sacriste, Antoine Vauchez, Laurent Willemez. Sur la portée sociale du droit. Usages et légitimité du registre juridique, Curapp-Presses Universitaires de France, pp.187-200.

Hess, J.D. 2009. Localist Movements in a Global Economy. Sustainability, Justice, and Urban Development in the United States. MIT press, Cambridge, Massachussets, London, England.

Hobbs, R.J., Higgs, E., Harris J.A. 2009. Novel ecosystems: implications for conservation and restoration. TREE 24:599-605

Hornoy, B., Tarayre, M., Hervé, M., Gigord, L., Atlan, A., 2011. Invasive Plants and Enemy Release: Evolution of Trait Means and Trait Correlations in Ulex Europaeus. PLoS ONE 6: e26275.

Humair, F., Edwards, P.J., Siegrist, M., Kueffer, C., 2014. Understanding misunderstandings in invasion science: why experts don't agree on common concepts and risk assessments. NeoBiota 20, 1-30.

Isern, D.T., 2007. A good servant but a tyrannous master: Gorse in New Zealand. Soc Sci J 44, 179-186.

Jacob de Cordemoy, E., 1895. Flore de l'île de La Réunion (Phanérogames, Cryptogames vasculaires, Muscinées) avec l'indication des propriétés économiques, et industrielles des plantes. Librairie médicale et scientifique Jacques Lechevalier, Paris.

Javelle, A, Kalaora, B, Decocq, G., 2006. Les aspects sociaux d'une invasion biologique en forêt domaniale de Compiègne : la construction sociale de Prunus serotina. Nat.Sci. Sociétés Vol. 14:278-285.

Kueffer C., Vos P., 2003. Woody invasive species in the western indian ocean: a regional assessment. Proc. Reg. Workshop Invasive Alien Species Terr. Ecosyst. Rehabil. West. Indian Ocean IsI. States Seychelles - 13th 17th Oct. 2003 22-33.

Kull, C.A., Harimanana, S.L.; Radaniela Andrianoro, A. Rajoelison, L.G. This issue. Divergent perceptions of the 'neo-Australian' forests of lowland eastern Madagascar: invasions, transitions, and livelihoods. J. Environ. Manage.

Larson, B.M.H., 2007. An alien approach to invasive species: objectivity and society in invasion biology. Biol. Invasions 9, 947-956.

Lavergne, R., 1978. Les Pestes Végétales de L'île de La Réunion. Info-Nature 16, 9-60.

Lavergne, R., 1980. Les 'zépinards' du Maido et de La Plaine Des Cafres. In Fleurs de Bourbon. Vol. 2. Sainte-Clothilde, La Réunion.

Le Petit Futé, 2013. Réunion. Country guide. Paris: Nouvelles éd. de l'Université.

Leblond, M.A., Martineau, A., 1931. L'île de La Réunion. Société d'éditions géographiques, Maritimes et coloniales.

Linton, R., 1945. The Cultural Background of Personality, D. Appleton. New York.

Lowe, S., Browne, M., Boudjelas, S., De Poorter, M., 2000. 100 of the world's worst invasive alien species: a selection from the global invasive species database. Invasive Species Specialist Group Species Survival Commission, World Conservation Union (IUCN), Auckland, New Zealand .

Mack, R., 2001. Motivations and Consequences of the Human Dispersal of Plants. In The Great Reshuffling: Human Dimensions of Invasive Alien Species, UICN, 23-34. Jeffrey A. McNeely.

Menozzi, M.-J., 2010. Comment catégoriser les espèces exotiques envahissantes. Éditions de l'EHESS

Migot, P., 2006. Gestions durables des espèces animales (mammifères, oiseaux) - Approches biologiques, juridiques et sociologiques: Compte rendu de colloque (Paris, 15-17 novembre 2004. Nat. Sci. Sociétés 14, 52-59. 
Moreau, J., 1975. Exposition de L'agriculture, de L'industrie et Des Arts À La Réunion. In L'album de L'île de La Réunion d'Antoine Roussin, Jeanne Laffitte, 1:169. Marseille.

Mougenot, C., Roussel, L., 2006. Peut-on Vivre Avec Le Ragondin ? Les représentations sociales reliées à un animal envahissant. Nat. Sci. Sociétés 14, 22-31.

Mougenot, C., Strivay, L., 2011. Le pire ami de l'homme : du lapin de Garenne aux guerres biologiques. Les Empêcheurs de Penser En Rond. Paris, La Découverte.

Murat, H., 2001. Nouvelles du bon temps de longtemps. La barre du jour. Vey L'embelli.

ONF, 1987. Les pâturages domaniaux de la Plaine des Cafres, Bilan des actions 1978-1987.

Payet, G., 2012. Impact d'un incendie sur un habitat naturel en cœur de Parc National: le cas du Maïdo, île de La Réunion (Océan Indien). Etat des lieux et suggestions pour une gestion conservatoire à court, moyen et long terme. La Réunion: Parc National de La Réunion et AgroParisTech. 108 p.

Raunet, M., 1991. Le milieu physique et les sols de l'île de La Réunion. Conséquences pour la mise en valeur. CIRAD, La Réunion.

Robert, R., 1998. La gestion et la valorisation du domaine public dans les Hauts de l'île de La Réunion (Océan Indien). Ann. Géographie 107 (603), 487-507

Parsons T., 1951. The social system, New York, the Free Press

Sigala, P., 2001. La lutte contre les pestes végétales sur le domaine forestier à La Réunion. Rev. For. Fr LIII.

Starfinger, U., Kowarik, I., Rode, M., Schepker, H., 2003. From desirable ornamental plant to pest to accepted addition to the flora? The perception of an alien tree species through the centuries. Biol. Invasions 5, 323-335.

Strasberg, D., Rouget, M., Richardson, D.M., Baret, S., Dupont, J., Cowling, R.M., 2005. An assessment of habitat diversity and transformation on La Réunion island (Mascarene Islands, Indian Ocean) as a basis for identifying broad-scale conservation priorities. Biodivers. Conserv. 14, 3015-3032

Tassin, J., Riviere, J.N., Cazanove, M., Bruzzese, E., 2006. Ranking of invasive woody plant species for management on Reunion Island. Weed Res. 46, 388-403.

Thévenot, L., 2001. S'associer pour composer une chose publique, in Chopart, J.-N. et al. (eds), Actions associatives, solidarités et territoires, Saint-Etienne, Publications de l'Université de Saint Etienne, pp.267-274.

Thiann-Bo Morel, M., Duret, P., 2011. Rapport scientifique sur la construction sociale des Espèces Exotiques Envahissantes à La Réunion. La Réunion, 2011, $159 \mathrm{p}$.

Triolo, J., Hoff, M., 2006. Stratégie de lutte contre l'ajonc d'Europe (Ulex Europaeus) dans les Hauts de l'Ouest.

Schlaepfer, M.A. 2018. Do non-native species contribute to biodiversity? PLoS Biol. 17;16(4):e2005568

Shackleton, R.T., Shackleton, C.M. Kull, C.A. This issue. The role of invasive alien species in shaping local livelihoods and human well being: a review. J. Environ. Manage.

Udo, N., 2016. Quels sont les facteurs naturels et humains conduisant au statut invasif ? Le cas de l'ajonc d'Europe sur l'île de La Réunion. PdD diss. Université de Rennes 1

Udo, N., Darrot, C., Tarayre, M., Atlan, A., 2016. Histoire naturelle et humaine d'une invasion biologique. L'ajonc d'Europe sur l'île de La Réunion. Rev. Ethnoéco.

Udo, N., Darrot, C., Atlan, A., 2018. Espèce nuisible, espèce invasive: des statuts publics inscrits dans la succession des lectures du monde. Le cas de l'ajonc d'Europe sur l'île de La Réunion. Actes du colloque "Sales bêtes! Mauvaises herbes ! « Nuisible », une notion en débat".

UNESCO, 2013. Pitons, Cirques et Remparts de La Réunion (France) - Décision Suite Au Rapport de Mission SOC2013

Vailland, R., 1964. La Réunion, Lausanne, Rencontre

van Dam, P.J.E.M., 2001. Status loss due to ecological success. Landscape change and the spread of the rabbit. Innov. Eur. J. Soc. Sci. Res.14, 157-170.

van Sittert, L., 2002. Our irrepressible fellow-colonist: the biological invasion of prickly pear (Opuntia ficusindica) in the Eastern Cape c.1890-c.1910. J. Hist. Geogr. 28, 397-419.

Vaxelaire, D., 2012. L'histoire de la Réunion. Vol. 2. De 1848 à 2012. Le grand livre. Orphie.

Weber, M. [1921] 1995. Economie et société, Paris Pocket. 